\title{
Effects of Dietary Supplementation with Rice Distiller Dried Grain on Growth Performance and Digestibility of Growing Pigs
}

\author{
Yin Yin Kyawt, Bo Bo Hein, Kaung Si Thu Hein, Nay Thu Hein, Len Hung, Nang Ai Mon \\ Mon Hwan, Aye Chan Oo, Aung Paing Soe Oo, Khant Zin Oo, Thant Zin Oo, Min Htut \\ Oo, Khin Sandar Myint, Soe Min Thein, Min Aung*, Khin San Mu
}

\section{Department of Animal Nutrition, University of Veterinary Science, Yezin, Nay Pyi Taw, 15013, Myanmar}

\begin{abstract}
This experiment was conducted to determine the effects of dietary supplementation of rice distiller dried grain $(\mathrm{rDDG})$ on growth performance and digestibility of growing pigs. Fifteen growing pigs $(30 \pm 1.3 \mathrm{~kg})$ were assigned into 5 groups with 3 replicates, supplied with diet including different levels of rDDG 0\% (rDDG-00), 5\% (rDDG-5), 10\% (rDDG-10), 15\% (rDDG-15) and 20\% (rDDG-20) respectively for 10 weeks. Free assess to water with nipples were provided for pigs. Weekly cumulative feed intake, body weight gain and feed conversion ratio (FCR) were estimated. Also, feed digestibility and feed cost per $\mathrm{kg}$ of feed and body weight were determined. The rDDG possessed a high crude protein $(50.19 \%)$ and energy content $(3005 \mathrm{Kcal} / \mathrm{kg})$. Cumulative feed intake were not significantly different, however, body weight gain of pigs from rDDG-15 and rDDG-20 groups were significantly lower than the other groups at week-10. Lower cumulative feed conversion ratios (FCR) were observed in pigs from rDDG05 and rDDG-10 in comparison with rDDG-00, rDDG-15 and rDDG-20 at week-8, 9 and 10 . The digestibility of experimental feeds was not significantly different between groups. The feed cost was reduced about $30 \mathrm{MMK} / \mathrm{kg}$ feed for every $5 \%$ increasing of rDDG inclusion in diet. The lowest feed costs per kg BW were observed in rDDG-05 and rDDG-10 and followed by rDDG-15, rDDG-20 and rDDG-00. Thus, dietary supplementation of rice distiller dried grain (rDDG) up to $10 \%$ of diet improved growth performance and decreased feed cost per $\mathrm{kg}$ of body weight of growing pigs.
\end{abstract}

Keywords | Rice distiller dried grain, Growing pigs, Performance, Digestibility, Feed cost

\footnotetext{
Received | June 25, 2019; Accepted | August 19, 2019; Published | October 25, 2019

*Correspondence | Min Aung, Department of Animal Nutrition, University of Veterinary Science, Yezin, Nay Pyi Taw, 15013, Myanmar; Email: minaung.uvs@ gmail.com

Citation | Kyawt YY, Hein BB, Hein KST, Hein NT, Hung L, Hwan NAMM, Oo AC, Oo APS, Oo KZ, Oo TZ, Oo MH, Myint KS, Thein SM, Aung M, Mu KS (2019). Effects of dietary supplementation with rice distiller dried grain on growth performance and digestibility of growing pigs. Adv. Anim. Vet. Sci. 7(11): 986-993.
}

DOI | http://dx.doi.org/10.17582/journal.aavs/2019/7.11.986.993

ISSN (Online) | 2307-8316; ISSN (Print) | 2309-3331

Copyright (C) 2019 Aung et al. This is an open access article distributed under the Creative Commons Attribution License, which permits unrestricted use, distribution, and reproduction in any medium, provided the original work is properly cited.

\section{INTRODUCTION}

$\mathrm{T}$ he demand for animal protein for human nutrition in the developing countries is still rising, especially for pork and poultry products (OECD, 2010). One key of reducing poverty and developing rural areas is investment in the livestock sector through raising smallholder incomes via improved livestock productivity. In recent years, there has been significant increase in numbers of pigs raised under both small private and large commercial scales in Myanmar.
In swine production system, feed costs represented $65-75 \%$ of the production cost or even more nowadays. Thus, nutritionists have to look for alternative feeds to reduce the feed cost without detrimental effects on animal performance. Balanced pig diets contain two main components which are energy and protein, supplied mainly through corn and soybean meal.

As the price of cereal grains continues to increase, the demand for alternative feed ingredients such as dried grains (DDG) or DDG with soluble (DDGS) which provide energy and protein sources to livestock diets will also in- 
crease. The distiller dried grains (DDG and DDGS) are the cereal by-product which is fermented and distilled to obtained alcoholic beverage. The nutritive values of DDG and DDGS were $20-50 \%$ crude protein (CP), $96 \%$ organic matter $(\mathrm{OM}), 6 \%$ ether extract (EE), 15\% crude fiber (CF) (El-Hack et al., 2019) and 2,490 to $3,190 \mathrm{kcal} / \mathrm{kg}$ DM (dry matter) in metabolizable energy (ME) (Batal and Dale, 2006). Moreover, Nyachoti et al. (2005) and Widyaratne and Zijlstra (2007) stated that DDGS contains large quantities of nutrients including energy, crude protein $(\mathrm{CP})$ and non-phytate phosphorus; hence, it has the potential for being used as livestock feed, especially to mono-gastrics like pigs and poultry.

During recent years, several studies investigated the nutritive value of DDGS, which showed that DDGS level up to $10 \%$ (Whitney et al., 2006a), 20\% (Stein and Kees, 2007) or 30\% (Senne et al., 1996; Cook et al., 2005; DeDecker et al., 2005) could be fed to growing and finishing pigs without detrimental effect on their growth performance. However, Senne et al. (1996) and Widyaratne et al. (2004) reported that DDGS of $40 \%$ resulted in decreased average daily body weight gain (ADG) and feed intake. Moreover, Fu et al. (2004) and Widyaratne et al. (2004) deducted decreased performance at any level. This inconsistent results in growth performance of growing pigs, might be due to batch-to-batch variation in drying methods, levels of residual sugar, grain quality (Rausch and Belyea, 2006) and variation in palatability between sources (rice, wheat, corn) which could influence animal's performance (Hastad et al., 2005).

In Myanmar, there were a lot of brewer factories which produced huge amount of distiller grains every day. Those distiller grains, both wet and dry were conventionally used as livestock feed since many years ago; however, there were no report on the efficient utilization of distiller grains as animal feed. Thus, require further investigation on the efficient utilization of distiller grains produced in Myanmar as animal feed. Therefore, this experiment was conducted to investigate the effects of different levels of rice distiller dried grain (rDDG) on growth performance and digestibility of growing pigs.

\section{MATERIALS AND METHODS}

\section{Collection of Rice Distiller Dried Grain and OTHER FEED INGREDIENTS}

The main-feed ingredients which are maize, soybean meal, oil, oyster shell, di-calcium phosphate (DCP), lysine, methionine, $\mathrm{NaCl}$, toxinil and feedmix were purchased from commercial feed shop. The rice distiller wet grain (rDWG), non-genetically modified byproduct was obtained from Grand Royal Group International Co, Ltd., Yangon. The rDWG were dried for 3-4 days under the sunshine before inclusion in swine feed.

Experimental Design and Animals' Management This experiment was carried out at the research farm of University of Veterinary Science, Nay Pyi Taw, Myanmar and approved by the post graduate supervisory committee. Fifteen pigs (DYL breeds), $30 \pm 1.3 \mathrm{~kg}$ and 10 weeks old with equal sex ratio were randomly allocated into five groups with three replicates in each. All pigs were housed in individual pen and supplied with clean fresh water ad libitum, while feed twice daily. Before starting all pigs were administered ivermectin based on their body weight to prevent internal parasites. All excreta were cleaned out twice daily to prevent foul smelling. The experimental period was 10 weeks and the digestion trial was made at the last 5 days of the experimental period.

The five experimental diets were isocalorigenous and isonitrogenously formulated to meet the nutrient requirements of growing pigs according to NRC (1998). Experimental diets used in this experiment were:

Group 1 (rDDG-00): Diet containing 0\% rDDG Group 2 (rDDG-05): Diet containing 5\% rDDG Group 3 (rDDG-10): Diet containing 10\% rDDG Group 4 (rDDG-15): Diet containing 15\% rDDG Group 5 (rDDG-20): Diet containing 20\% rDDG

The diet composition and nutritive values of experimental diets were shown in Table 1 and Table 2, respectively.

\section{Growth Performance and Digestibility}

\section{Measurements}

During the experimental period, daily feed intake was recorded to calculate cumulative feed intake per week. Body weight measurement was carried out weekly and cumulative body weight gains were determined. Based on the cumulative feed intake and body gain, cumulative feed conversion ratio (FCR) was calculated. Feed cost per $\mathrm{kg}$ of body weight was also estimated.

During the digestion trial, feed offered were weighed before feeding and also feed refusals next morning were weighed to calculate feed intake. The feces voided from each pig were weighed and $100 \mathrm{~g}$ was collected for analysis. Fecal samples were added to $5 \mathrm{ml}$ of $10 \%$ formalin. All samples were dried under the sun until constant weight is obtained for further analysis. The feed offered, feed refusal and feces samples were analyzed for dry matter (DM) to calculate the DM digestibility (DMD) of experimental pigs.

Chemical composition analysis of rice distiller dried grain The chemical composition analysis was performed at the Laboratory of the Department of Physiology and Biochemistry, University of Veterinary Science, Yezin, Nay Pyi 
Table 1: Ingredient compositions of experimental diets

\begin{tabular}{llllll} 
Ingredients & \multicolumn{2}{l}{ Experimental diets } & & & \\
& rDDG-00 & rDDG-05 & rDDG-10 & rDDG-15 & rDDG-20 \\
Maize & 71.30 & 72.62 & 73.58 & 74.95 & 74.46 \\
\hline Soybean meal & 21.50 & 15.50 & 10.00 & 4.20 & 0.00 \\
DDG & 0.00 & 5.00 & 10.00 & 15.00 & 20.00 \\
\hline Oil & 4.28 & 3.60 & 2.90 & 2.20 & 1.88 \\
Oyster shell & 1.30 & 1.41 & 1.35 & 1.42 & 1.42 \\
DCP & 1.00 & 1.00 & 1.20 & 1.21 & 1.21 \\
Lysine & 0.10 & 0.30 & 0.40 & 0.45 & 0.46 \\
Methionine & 0.10 & 0.10 & 0.10 & 0.10 & 0.10 \\
NaCl & 0.20 & 0.25 & 0.25 & 0.25 & 0.25 \\
Toxinil & 0.02 & 0.02 & 0.02 & 0.02 & 0.02 \\
Feedmix & 0.20 & 0.20 & 0.20 & 0.20 & 0.20 \\
Total & 100.00 & 100.00 & 100.00 & 100.00 & 100.00
\end{tabular}

rDDG: rice distillers dried grain, DCP: dicalcium phosphate

Table 2: Nutritive values of experimental diets

\begin{tabular}{llllll} 
Nutritive values & \multicolumn{2}{l}{ Experimental diets } & & & \\
& rDDG-00 & rDDG-05 & rDDG-10 & rDDG-15 & rDDG-20 \\
ME, Kcal & 3264 & 3266 & 3263 & 3264 & 3270 \\
\hline CP, \% & 16.27 & 16.28 & 16.36 & 16.28 & 16.71 \\
\hline Calcium, \% & 0.76 & 0.78 & 0.79 & 0.80 & 0.79 \\
\hline NPP, \% & 0.31 & 0.30 & 0.32 & 0.31 & 0.30 \\
\hline Sodium, \% & 0.16 & 0.16 & 0.16 & 0.16 & 0.16 \\
\hline Cloride, \% & 0.22 & 0.22 & 0.22 & 0.22 & 0.22 \\
\hline Lysine, \% & 0.92 & 1.01 & 1.01 & 0.96 & 0.90 \\
\hline Methionine, \% & 0.37 & 0.44 & 0.43 & 0.42 & 0.37
\end{tabular}

NPP: non-phytate phosphorus

Table 3: Chemical compositions of rice distiller dried grain ( $\mathrm{rDDG}$ )

\begin{tabular}{lllllllll} 
Sample & \multicolumn{9}{l}{ Chemical compositions (\%) } \\
& DM & OM & Ash & CP & NDF & ADF & ADL & EE \\
rDDG & 94.18 & 96.86 & 3.14 & 50.19 & 22.28 & 18.40 & 6.80 & 2.85
\end{tabular}

DM: dry matter, OM: organic matter, CP: crude protein, NDF: neutral detergent fibre, ADF: acid detergent fibre, ADL: acid detergent lignin, EE: ether extract. All chemical compositions except DM are dry matter basis.

Taw, Myanmar. The rDDG was analyzed for dry matter $(\mathrm{DM})$, organic matter $(\mathrm{OM})$, crude protein $(\mathrm{CP})$ and ether extract (EE) according to AOAC (1990). While, neutral detergent fibre (NDF), acid detergent fibre (ADF) and acid detergent lignin (ADL) were analyzed according to Goerging and Van Soest (1970). The metabolizable energy (ME) content of rDDG was calculated with the equation mentioned by Ginger-Reverdin et al. (1994) as follows: $\mathrm{ME}(\mathrm{MJ} / \mathrm{kg} \mathrm{DM})=[13.38+(0.0118 \mathrm{EE})-(0.00547 \mathrm{NDF})$ $+(0.0065 \mathrm{ADF})-(0.0378 \mathrm{ADL})+(0.00291 \mathrm{CP})]$.

Statistical Analysis

The data of feed intake, body weight gain and feed conver- sion ratio, digestibility and feed cost were analyzed by one way analysis of variance (ANOVA) using SPSS Software for windows version 16.0 (Chicago, SPSS Inc.) and the significance differences between means were determined by Duncan's Multiple Range Test (DMRT). Differences were considered significant at $p<0.05$ and data were expressed as mean.

Table 4: Energy content of rDDG

\begin{tabular}{lll} 
Sample & \multicolumn{3}{l}{ Metabolizable Energy (ME) } \\
& MJ/kg DM & Kcal $/ \mathbf{k g}$ DM \\
rDDG & 12.58 & 3005.05
\end{tabular}

rDDG: rice distiller dried grain 
Table 5: Cumulative Feed intake ( $\mathrm{kg} / \mathrm{head})$ of growing pig

\begin{tabular}{|c|c|c|c|c|c|c|c|}
\hline \multirow{2}{*}{$\begin{array}{l}\text { Experimental } \\
\text { period }\end{array}$} & \multicolumn{5}{|c|}{ Experimental diets (mean) } & \multirow[t]{2}{*}{ SEM } & \multirow[t]{2}{*}{ Pvalues } \\
\hline & $\begin{array}{l}\text { rDDG- } \\
00\end{array}$ & $\begin{array}{l}\text { rDDG- } \\
05\end{array}$ & $\begin{array}{l}\text { rDDG- } \\
10\end{array}$ & $\begin{array}{l}\text { rDDG- } \\
15\end{array}$ & $\begin{array}{l}\text { rDDG- } \\
20\end{array}$ & & \\
\hline Week-1 & 11.57 & 11.18 & 11.67 & 10.63 & 11.24 & 0.28 & 0.844 \\
\hline Week-2 & 23.15 & 22.35 & 23.34 & 21.26 & 22.48 & 0.56 & 0.844 \\
\hline Week-3 & 35.88 & 33.61 & 36.25 & 33.91 & 34.34 & 0.82 & 0.840 \\
\hline Week-4 & 50.05 & 47.75 & 50.37 & 48.54 & 49.00 & 0.95 & 0.932 \\
\hline Week-5 & 64.97 & 62.00 & 64.71 & 64.45 & 64.20 & 1.14 & 0.951 \\
\hline Week-6 & 80.47 & 77.30 & 78.92 & 79.73 & 79.71 & 1.47 & 0.979 \\
\hline Week-7 & 96.42 & 92.13 & 93.95 & 95.16 & 94.86 & 1.73 & 0.969 \\
\hline Week-8 & 111.87 & 106.92 & 108.47 & 110.70 & 110.14 & 2.01 & 0.963 \\
\hline Week-9 & 126.42 & 121.11 & 122.70 & 125.98 & 125.07 & 2.20 & 0.953 \\
\hline Week-10 & 139.87 & 133.81 & 136.21 & 139.61 & 138.33 & 2.42 & 0.949 \\
\hline
\end{tabular}

SEM: standard error mean

Table 6: Cumulative body weight gain ( $\mathrm{kg} / \mathrm{head})$ of growing pigs

\begin{tabular}{|c|c|c|c|c|c|c|c|}
\hline \multirow{2}{*}{$\begin{array}{l}\text { Experimental } \\
\text { period }\end{array}$} & \multicolumn{5}{|c|}{ Experimental diets (mean) } & \multirow[t]{2}{*}{ SEM } & \multirow[t]{2}{*}{ Pvalues } \\
\hline & $\begin{array}{l}\text { rDDG- } \\
00\end{array}$ & $\begin{array}{l}\text { rDDG- } \\
05\end{array}$ & $\begin{array}{l}\text { rDDG- } \\
10\end{array}$ & $\begin{array}{l}\text { rDDG- } \\
15\end{array}$ & $\begin{array}{l}\text { rDDG- } \\
20\end{array}$ & & \\
\hline Week-1 & 5.38 & 5.25 & 5.73 & 5.53 & 5.56 & 0.09 & 0.611 \\
\hline Week-2 & 9.28 & 8.50 & 9.33 & 8.79 & 8.79 & 0.25 & 0.849 \\
\hline Week-3 & 13.95 & 12.50 & 13.08 & 11.36 & 11.73 & 0.36 & 0.139 \\
\hline Week-4 & 18.83 & 17.88 & 18.58 & 16.56 & 16.56 & 0.44 & 0.336 \\
\hline Week-5 & 23.70 & 23.25 & 24.08 & 21.76 & 21.39 & 0.56 & 0.505 \\
\hline Week-6 & 28.58 & 28.63 & 29.58 & 26.96 & 26.22 & 0.69 & 0.599 \\
\hline Week-7 & 33.45 & 34.00 & 35.08 & 32.16 & 31.06 & 0.83 & 0.647 \\
\hline Week-8 & 40.00 & 41.78 & 41.64 & 37.61 & 36.32 & 0.97 & 0.296 \\
\hline Week-9 & 46.55 & 49.57 & 48.20 & 43.05 & 41.59 & 1.17 & 0.132 \\
\hline Week-10 & $53.10^{\mathrm{ab}}$ & $57.35^{\mathrm{a}}$ & $56.43^{\mathrm{a}}$ & $48.16^{b}$ & $46.86^{\mathrm{b}}$ & 1.46 & 0.040 \\
\hline
\end{tabular}

SEM: standard error mean

${ }^{a, b}$ Different superscripts in the same column are significantly different at $\mathrm{P}$ value 0.05 .

\section{RESULTS}

The chemical composition and energy content of rDDG were showed in Table 3 and 4 respectively. The cumulative feed intake of pigs were described in Table 5 , in which non-significant differences $(p>0.05)$ were observed between groups throughout the experimental period, however, the cumulative feed intake at week-10 of pigs fed on rDDG-05 and rDDG-10 were lower than those of other groups.

The cumulative body weight gains were not significantly different ( $p>0.05$ ) from week-1 to week-9 between groups, however there was a significant difference $(p<0.05)$ observed at week-10, as the highest $(p<0.05)$ cumulative body weight gain were observed in pigs fed on rDDG05 and $\mathrm{rDDG}-10$, followed by $\mathrm{rDDG}-00, \mathrm{rDDG}-15$ and rDDG-20 as shown in Table 6.
The FCR were shown in Table 7. The FCR of all treatments were not significantly different $(p<0.05)$ from week1 to week-7 of experimental period. At week-8, 9 and 10, FCR of growing pig were significantly different $(p<0.05)$, where pigs fed on rDDG-05 and rDDG-10 groups had the lowest FCR $(\mathrm{p}<0.05)$, followed by rDDG-00, rDDG15 and rDDG-20 groups. The FCR of growing pigs in rDDG-00 group was not significantly different $(p>0.05)$ from $\mathrm{rDDG}-15$ and $\mathrm{rDDG}-20$.

The apparent total tract digestibility of dry matter (ATTD-DM) showed non- significant difference $(p>0.05)$, however the highest digestibility value was found in rDDG-05 (83.25\%), followed by rDDG-10 (82.95\%), rDDG-00 (82.67\%), rDDG-15 (82.63\%) and rDDG-20 (82.44\%) as found in Table 8.

The feed cost per kg of diet was shown in Table 9. Every 
Table 7: Cumulative feed conversion ratios (FCR) of growing pigs

\begin{tabular}{|c|c|c|c|c|c|c|c|}
\hline \multirow{2}{*}{$\begin{array}{l}\text { Experimental } \\
\text { period }\end{array}$} & \multicolumn{5}{|c|}{ Experimental diets (mean) } & \multirow[t]{2}{*}{ SEM } & \multirow[t]{2}{*}{$p$ values } \\
\hline & $\begin{array}{l}\text { rDDG- } \\
00\end{array}$ & $\begin{array}{l}\text { rDDG- } \\
05\end{array}$ & $\begin{array}{l}\text { rDDG- } \\
10\end{array}$ & $\begin{array}{l}\text { rDDG- } \\
15\end{array}$ & $\begin{array}{l}\text { rDDG- } \\
20\end{array}$ & & \\
\hline Week-1 & 2.15 & 2.13 & 2.04 & 1.94 & 2.02 & 0.05 & 0.783 \\
\hline Week-2 & 2.50 & 2.63 & 2.50 & 2.42 & 2.58 & 0.04 & 0.636 \\
\hline Week-3 & 2.58 & 2.69 & 2.77 & 2.99 & 2.93 & 0.06 & 0.113 \\
\hline Week-4 & 2.67 & 2.67 & 2.71 & 2.94 & 2.96 & 0.05 & 0.067 \\
\hline Week-5 & 2.76 & 2.67 & 2.69 & 2.97 & 3.00 & 0.05 & 0.057 \\
\hline Week-6 & 2.85 & 2.70 & 2.67 & 2.96 & 3.04 & 0.05 & 0.084 \\
\hline Week-7 & 2.92 & 2.71 & 2.68 & 2.97 & 3.06 & 0.06 & 0.138 \\
\hline Week-8 & 2.82 & 2.56 & 2.60 & 2.94 & 3.03 & 0.06 & 0.013 \\
\hline Week-9 & $2.74^{\mathrm{ab}}$ & $2.44^{\mathrm{c}}$ & $2.55^{\mathrm{bc}}$ & $2.92^{\mathrm{a}}$ & $3.00^{\mathrm{a}}$ & 0.07 & 0.003 \\
\hline Week-10 & $2.66^{\mathrm{ab}}$ & $2.33^{c}$ & $2.42^{\mathrm{bc}}$ & $2.90^{\mathrm{a}}$ & $2.95^{\mathrm{a}}$ & 0.07 & 0.002 \\
\hline
\end{tabular}

SEM: standard error mean

a,b,c Different superscripts in the same column are significantly different at $\mathrm{P}$ value 0.05 .

Table 8: Apparent total tract digestibility of dry matter (ATTD-DM) of growing pigs

\begin{tabular}{lllllllll} 
Description & \multicolumn{2}{l}{ Experimental diets (mean) } & & & & \\
& rDDG- & rDDG- & rDDG- & rDDG- & rDDG- & SEM & P value \\
& $\mathbf{0 0}$ & $\mathbf{0 5}$ & $\mathbf{1 0}$ & $\mathbf{1 5}$ & $\mathbf{2 0}$ & & \\
ATTD-DM & 82.67 & 83.25 & 82.95 & 82.63 & 82.44 & 0.28 & 0.930
\end{tabular}

SEM: standard error mean

Table 9: Feed cost per kg of diets and body weight (BW)

\begin{tabular}{llllllll} 
Feed cost (MMK) & \multicolumn{2}{l}{ Experimental diets (mean) } & & SEM & P value \\
& rDDG- & rDDG- & rDDG- & rDDG- & rDDG- \\
& $\mathbf{0 0}$ & $\mathbf{0 5}$ & $\mathbf{1 0}$ & $\mathbf{1 5}$ & $\mathbf{2 0}$ & - \\
Cost/kg feed & 583 & 554 & 526 & 493 & 473 & - & - \\
\hline Cost/kg BW & $1400^{\mathrm{a}}$ & $1158^{\mathrm{b}}$ & $1161^{\mathrm{b}}$ & $1240^{\mathrm{ab}}$ & $1310^{\mathrm{ab}}$ & 29.5 & 0.020
\end{tabular}

MMK: Myanmar kyat

SEM: standard error mean

${ }^{\mathrm{a}, \mathrm{b}}$ Different superscripts in the same column are significantly different at $\mathrm{P}$ value 0.05 .

$5 \%$ increase in the inclusion rate of $\mathrm{rDDG}$ in diet; the feed cost was reduced by about $30 \mathrm{MMK} / \mathrm{kg}$ of feed. Moreover, the feed costs per $\mathrm{kg}$ body weight presented in Table 9 showed significant variation $(p<0.05)$, as the lowest feed cost per kg BW were observed in rDDG-05 (1158 MMK/ $\mathrm{kg}$ BW) and rDDG-10 (1161 MMK/kg BW), followed by rDDG-15 (1240 MMK/kg BW), rDDG-20 (1310 $\mathrm{MMK} / \mathrm{kg} \mathrm{BW}$ ) and rDDG-00 (1400 MMK/kg BW).

\section{DISCUSSION}

The crude protein $(\mathrm{CP})$ of $\mathrm{rDDG}$ was $50.19 \%$, which is slightly lower than that reported by Taranu et al. (2018) which was $70.40 \%$. This could be due to difference in the raw material used and ethanol extraction method for alcohol production of distilleries. Although, this high protein content of $\mathrm{rDDG}$ could indicate that the fermentation as well as alcohol processing period increased the protein content of raw rice. However, the rDDG contained more protein content than corn DDG which ranged from 12-32 \% (Spiehs et al., 2002; Belyea et al, 2010; Liu, 2011; Taranu et al., 2018). Moreover, increasing the inclusion level of wheat DDG in diet reduced dietary protein and energy digestibility (Wang et al., 2016). Le Gall et al. (2009) stated that increasing wheat DDG lead to high dietary NDF content that is negatively correlated with coefficient ATTD of gross energy (GE).

The Metabolizable energy (ME) of rDDG (3005.05 kcal/ $\mathrm{kg} \mathrm{DM}$ ) was lower than that of that reported by Taranu et al. (2018) that was $4952 \mathrm{kcal} / \mathrm{kg}$ DM and of corn DDGS (3897 kcal/kg DM) (Stein and Shurson, 2009). This could be explained by Ortin and $\mathrm{Yu}$ (2009) who reported that the final product features are mainly influenced by the initial ingredient (variety, quality and type of grain, as well as environmental conditions), and the processing conditions 
(temperature, cooking time, distillation, dehydration and pelleting, etc.).

The cumulative feed intake was not significantly different, this might be attributed to no change in feed palatability, which influenced the feed intake of animals, and this means that the increased inclusion of rDDG in diets did not affect the palatability. Moreover, the source of distiller dried grain (DDG) is one of the factors that influence the feed intake of animals. Some distiller dried grains are from the grain with husk (eg. wheat), while other without husk (eg. rice), in which the husk is comprised of insoluble fiber. Thus increasing the inclusion level of DDG from grain with husk (eg. Wheat) increased the insoluble fiber content in diet, which lead to low feed intake in mono-gastric animal as stated by Hastad et al. (2005) that reduced feed intake may have been related to the specific source of DDG used.

On the other hand, Gowans et al. (2007) and Kerr et al. (2015) stated that the inclusion of corn DDG by $30 \%$ and $40 \%$ had no influence on average daily feed intake (ADFI) of growing pigs. Moreover, Senne et al. (1996) reported that addition of sorghum DDG to grower-finisher diet at level up to $30 \%$, showed no effect on ADFI. However, the higher inclusion rates reduced ADFI (Senne et al., 1996; Feoli et al., 2007). Thacker (2006) found that inclusion of wheat DDG at levels of $0,5,10,15,20$, or $25 \%$ in growing pig's diets, lead to a linear reduction of ADFI.

Higher cumulative body weight gains were observed in rDDG-05 and rDDG-10, while, reduced in rDDG-15 and rDDG-20, that was similar to Whitney et al. (2006b) and Linneen et al. (2008) who showed a linear decrease in average daily gain (ADG) by feeding diets containing 0 , 10,20 , or $30 \%$ DDGS, with the most decrement in those fed diets containing greater than 10\% DDGS. Moreover, Cromwell et al. (1993) stated that inclusion of corn DDG up to $30 \%$ in growing pig's diet reduced the ADG. On contrary, no changes in ADG by corn DDG were observed by Kerr et al. (2015). Moreover, feeding sorghum DDG up to $30 \%$ in grower-finisher diets showed no influence on ADG (Senne et al., 1996). Widyaratne and Zijlstra (2007) reported that inclusion of wheat DDG did not affect ADG. However, the higher inclusion rate of sorghum DDG reduces ADG (Senne et al., 1998; Feoli et al., 2007). Thacker (2006) showed linear reduction in ADG by feeding up to $25 \%$ wheat DDG in growing pig's diet. These inconsistent responses of usage of DDGS in growing pig might be due to the differences in palatability of DDGS and feeding stage of pig used in those experiments.

The FCR was lower in rDDG-05 and rDDG-10 which could be attributed to the higher body weight gain, although feed intakes were not different. Similarly, feeding sorghum and corn DDGS up to 30\% showed no effect on FCR or feed efficiency (Senne et al., 1996, Kerr et al., 2015), however it was reduced with the higher inclusion rates (Senne et al., 1998; Feoli et al., 2008). Moreover, adding $25 \%$ wheat DDG to a growing-finishing diet, had no effects on feed efficiency (Thacker, 2006; Widyaratne and Zijlstra, 2007).

No difference in ATTD-DM was observed, similarly to the report of Kerr et al. (2015), who stated that the inclusion of corn DDG up to $30 \%$ in growing-finishing ration did not affect the ATTD-DM of experimental pigs. Moreover, the dry matter digestibility of animal is related to the feed intake, thus, increased feed intake caused the decrease of digestibility and vice versa. In this experiment, the feed intake was not different for all groups, which resulted in no influence on ATTD-DM. On the other hand, Knudsen and Canibe (2000) deducted that wheat DDG contains insoluble fiber, thus, its digestibility is expected to be low. However, the DDG used in this experiment is from the rice without husk, thus, although the inclusion level of rDDG is increased (in replace to corn) in diets, the insoluble fiber content of diet was not changed, which resulted in no significant change in ATTD-DM.

The feed cost was reduced about $30 \mathrm{MMK} / \mathrm{kg}$ feed for every $5 \%$ increase of rDDG inclusion in diets which might be due to the difference in the price between soybean meal and rDDG. The inclusion levels of soybean meal and rDDG for rDDG-00 were (21.50 and 0.00\%), rDDG05 (15.50 and 5.00\%), rDDG-10 (10.00 and 10.00\%), rDDG-15 (4.20 and 15.00\%) and rDDG-20 (0.00 and $20.00 \%)$ respectively. Thus, with the increased inclusion of rDDG, the soybean meal decreased, resulting in decreased feed cost. Stein and Shurson (2009) explained that each $10 \%$ increase in DDGS in the ration reduced the feed price per 100 pounds by approximately $\$ 0.25$ to 0.28 .

The lowest feed cost per $\mathrm{kg}$ body weight observed in rDDG-05 and rDDG-10 are attributed to differences in feed cost per $\mathrm{kg}$ feed, body weight gain and feed conversion ratio. The feed cost per $\mathrm{kg}$ of rDDG-05 and rDDG10 is cheaper than rDDG-00 (control), and more expensive than rDDG-15 and rDDG-20, however, the highest body weight gain and the lowest feed conversion ratio were observed in rDDG-05 and rDDG-10. Stein and Shurson (2009) stated that the feed cost per gain was reduced by $\$ 3$ to $\$ 7 /$ head by adding DDGS to the diet. Thus, depending on DDG price and nutrient content, as well as the cost of other feed ingredients, a reduction in feed cost per $\mathrm{kg}$ of feed and body weight gain could be varied.

\section{CONCLUSIONS}

It could be concluded that the pigs fed on rice distiller 
dried grain (rDDG) at the level of 5\% and 10\% showed the highest body weight gain and lowest feed conversion ratio. Moreover the feed cost per $\mathrm{kg}$ of body weight were also the lowest. Thus, dietary supplementation with rice distiller dried grain (rDDG) up to level of $10 \%$ in diet could improve the growth performance and decreased the feed cost per $\mathrm{kg}$ of body weight of growing pigs.

\section{ACKNOWLEDGEMENT}

The authors would like to thanks the staff from the laboratory of Animal Nutrition, and Physiology and Biochemistry for their assistance in chemical analysis and animal care. We also would like to express our thanks to Grand Royal Group International Co, Ltd., Yangon for their finicial supports to conduct this experiment as well.

\section{CONFLICT OF INTEREST}

There is no conflict of interest.

\section{AUTHOR'S CONTRIBUTION}

YYK, BBH, KSTH, NTH, LH, NAMMH, ACO, APSO, $\mathrm{KZO}$, TZO, MHO, KSDM, SMT, MA and KSM designed this experiment and, YYK, BBH, KSTH, NTH, $\mathrm{LH}, \mathrm{NAMMH}, \mathrm{ACO}, \mathrm{APSO}, \mathrm{KZO}, \mathrm{TZO}, \mathrm{MHO}$ and MA mainly carried out sample collection and analyzed the chemical compositions. YYK, KSM and MA performed data analysis and interpretation. YYK, BBH, KSTH, NTH, LH, NAMMH, ACO, APSO, KZO, TZO and MHO drafted the manuscript and KSDM, SMT, KSM and MA completed the critical revision of the article. All authors read and approved the final version of manuscript.

\section{REFERENCES}

-AOAC (1990). Official Methods of Analysis, $15^{\text {th }}$ ed. Association of Official Analytical Chemists. Washington DC. pp.69-88.

- Batal AB, Dale NM (2006). True metabolizable energy and amino acid digestibility of distillers dried grains with solubles. J. Appl. Poult. Res. 15:89-93. https://doi. org/10.1093/japr/15.1.89

-Belyea RL, Rauschb KD, Clevengerc TE, Singhb V, Johnstond DB, Tumblesonc ME (2010). Sources of variation in composition of DDGS. Anim. Feed Sci. Tech. 159(3):122130. https://doi.org/10.1016/j.anifeedsci.2010.06.005

- Cook D, Paton N, Gibson M (2005). Effect of dietary level of distillers dried grains with solubles (DDGS) on growth performance, mortality, and carcass characteristics of growfinish barrows and gilts. J. Anim. Sci. 83(Suppl. 1):335 (Abstr.).

- Cromwell GL, Herkelman KL, Stahly TS (1993). Physical, chemical and nutritional characteristics of distillers dried grains with solubles for chicks and pigs.J.Anim. Sci. 71:679686. https://doi.org/10.2527/1993.713679x

- DeDecker JM, Ellis M, Wolter BF, Spencer J, Webel DM,
Bertelsen CR, Peterson BA (2005). Effects of dietary level of distillers dried grains with solubles and fat on the growth performance of growing pigs. J. Anim. Sci. 83(Suppl. 2):79 (Abstr.).

-El-Hack ME, Alagawany AM, Patra A, Abdel-Latif M, Ashour EA, Afir M, Farag MR, Dhama K (2019). Use of brewers dried grains as an unconventional feed ingredient in the diets of broiler chiken: A Review. Advan. Anim. Vet. Sci. 7(3):218-224. https://doi.org/10.17582/journal. aavs/2019/7.3.218.224

-Feoli C, Hancock JD, Gugle TL, Carter SD (2008). Effects of expander conditioning on the nutritional value of diets with corn-and sorghum-based distillers dried grains with solubles in nursery and finishing diets. J. Anim. Sci. 86(Suppl. 2):50 (Abstr.). https://doi.org/10.4148/2378-5977.7023

- Feoli C, Hancock JD, Monge C, Gugle TL, Carter SD, Cole NA (2007). Effects of corn and sorghum-based distillers dried grains with solubles on growth performance and carcass characteristics in finishing pigs. J. Anim. Sci. 85(Suppl. 2):95 (Abstr.). https://doi.org/10.4148/2378-5977.6995

- Fu SX, Johnston M, Fent RW, Kendall DC, Usry JL, Boyd RD, Allee GL (2004). Effect of corn distillers dried grains with solubles (DDGS) on growth, carcass characteristics, and fecal volume in growing finishing pigs. J. Anim. Sci. 82(Suppl. 2):80 (Abstr.).

- Ginger-Reverdin S, Aufrere J, Saurcant D, Demarquilly G, Vermorel M (1994). Prediction of the energy values of compound feeds for ruminant. Anim. Feed Sci. Technol. 48:73-98. https://doi.org/10.1016/0377-8401(94)90113-9

- Goering HK, Van Soest PJ (1970). Forage fibre analyses (apparatus, reagents, procedures, and some applications). Agriculture Handbook No. 379, Agric. Res. Serv. USDA, Washington, DC, USA, pp.20.

- Gowans J, Callaahan M, Yusupov A, Campbell N, Young M (2007). Determination of the impact of feeding increasing levels of corn dried distillers grains on performance of growing finishing pigs reared under commercial conditions. Adv. Pork. Prod. 18: A-22 (Abstr.)

- Hastad CW, Nelssen JL, Goodband RD, Tokach MD, Dritz SS, DeRouchey JM, Frantz NZ (2005). Effect of dried distillers grains with solubles on feed preference in growing pigs. J. Anim. Sci. 83(Suppl. 2):73 (Abstr.).

-Kerr BJ, Gabler NK, Shurson GC (2015). Formulating diets containing corn distillers dried grains with solubles on a net energy basis : Effects on pig performance and on energy and nutrient digestibility. Pro. Anim. Sci. 31:497-503. https:// doi.org/10.15232/pas.2015-01445

-Knudsen KEB, Canibe N (2000). Breakdown of plant carbohydrates in the digestive tract of pigs fed on wheator oat-based rolls. J. Sci. Food. Agri. 80:1253-1261. https:// doi.org/10.1002/1097-0010(200006)80:8\%3C1253::AIDJSFA632\%3E3.3.CO;2-S

-Le Gall M, Warpechowski M, Jaguelin-Peyraud Y, Noblet J (2009). Influence of dietary fibre level and pelleting on the digestibility of energy and nutrients in growing pigs and adult sows. Anim. 3:352-359. https://doi.org/10.1017/ S1751731108003728

-Linneen SK, DeRouchy JM, Dritz SS, Goodband RD, Tokach MD, Nelssen JL (2008). Effects of dried distillers grains with solubles on growing and finishing pig performance in a commercial environment. J. Anim. Sci. 86:1579-1587. https://doi.org/10.2527/jas.2007-0486

- Liu KS (2011). Chemical composition of distillers grains, a 
review. J. Agri. Food Chem. 59(5):1508-1526. https://doi. org/10.1201/b11047-3

- NRC (1998).National Research Council.Nutrient Requirements of Swine. $10^{\text {th }}$ Revised Edition. Then National Academies Press. Washington, DC.

- Nyachoti CM, House JD, Slominski BA, Seddon IR (2005). Energy and nutrient digestibilities in wheat dried distillers grains with solubles fed to growing pigs. J. Sci. Food Agric. 85:2581-2586. https://doi.org/10.1002/jsfa.2305

- OECD (2010). Organization for Economic Cooperation and Development and Food and Agriculture Organization of the United Nations. Meat. OECD-FAO Agricultural Outlook 2010. OECD Publishing. pp.147-158.

- Ortin WGN, Yu PQ (2009). Nutrient variation and availability of wheat DDGS, corn DDGS and blend DDGS from bioethanol plants. J. Agric. Food Chem. 89:1754-1761. https://doi.org/10.1002/jsfa.3652

- Rausch KD, Belyea RL (2006). The future of coproducts from corn processing. Appl. Biochem. Biotechnol. 128:47-86. https://doi.org/10.1385/ABAB:128:1:047

- Senne BW, Hancock JD, Hines RH, Dean DW, Mavromichalis I, Froetschner JR (1998). Effects of whole grain and distillers dried grains with solubles from normal and heterowaxy endosperm sorghums on growth performance, nutrient digestibility, and carcass characteristics of finishing pigs. Kansas State Univ. Swine Day Report. Kansas State Univ. Manhattan. pp.148-152. https://doi.org/10.4148/23785977.6588

- Senne BW, Hancock JD, Mavromichalis I, Johnston SL, Sorrell PS, Kim IH, Hines RH (1996). Use of sorghum-based distillers dried grains in diets for nursery and finishing pigs. Kansas State Univ. Swine Day Report. Kansas State Univ. Manhattan. pp.140-145. https://doi.org/10.4148/23785977.6502

- Spiehs MJ, Whitney MH, Shurson GC (2002). Nutrient database for distiller's dried grains with solubles produced from new ethanol plants in Minnesota and South Dakota. J. Anim. Sci. 80(10): 2639-2645. https://doi.org/10.1093/ ansci/80.10.2639

- Stein H, Kees DL (2007). Alternative feed ingredients for pigs. London Swine Conference-Today's Challenges; Tomorrow's Opportunities.3-4.
- Stein HH, Shurson GC (2009). The use and application of distillers dried grains with solubles in swine diets. J. Anim. Sci. 87:1292-1303. https://doi.org/10.2527/jas.2008-1290

- Taranu I, Nguyen TT, Pham KD, Gras MA, Pistol GC, Marin DE, Rotar C, Habeanu M, Ho PH, Le TM, Bui TTH, Mai DV, Chu-Kyu S (2018). Rice and cassava distillers dried grains in Vietnam: nutritional values and effects of their dietary inclusion on blood chemical parameters and immune responses of growing pigs. Waste and Biomass Valorization. https://doi.org/10.1007/s12649-018-0341-7.

- Thacker PA (2006). Nutrient digestibility, performance and carcass traits of growing-finishing pigs fed diets containing dried wheat distillers grains with solubles. Can. J. Anim. Sci. 86:527-529. https://doi.org/10.4141/A06-025

-Wang LF, Beltranena E, Zijlstra RT (2016). Diet nutrient digestibility and growth performance of weaned pigs fed wheat dried distillers grains with solubles (DDGS). Anim. Feed Sci. Technol. 218: 26-32. https://doi.org/10.1016/j. anifeedsci.2016.05.005

-Whitney MH, Shurson GC, Guedes RC (2006a). Effect of including distillers dried grains with solubles in the diet, with or without antimicrobial regimen, on the ability of growing pigs to resist a Lawsonia intracellularis challenge. J. Anim. Sci. 84:1870-1879. https://doi.org/10.2527/jas.2004575

-Whitney MH, Shurson GC, Johnson LJ, Wulf DM, Shanks BC (2006b). Growth performance and carcass characteristics of grower-finisher pigs fed high-quality corn distillers dried grain with solubles originating from a modern Midwestern ethanol plant. J. Anim. Sci. 84: 3356-3363. https://doi. org/10.2527/jas.2006-099

-Widyaratne GP, Zijlstra RT (2007). Nutritional value of wheat and corn distiller's dried grain with solubles: Digestibility and digestible contents of energy, amino acids and phosphorus, nutrient excretion and growth performance of grower-finisher pigs. Can. J. Anim. Sci. 87:103-114. https:// doi.org/10.4141/A05-070

-Widyaratne GP, Patience JF, Zijlstra RT (2004). Nutritional values of wheat and corn distillers dried grain with soluble (DDGS): Digestible energy (DE), amino acid and phosphorus content and growth performance of growerfinisher pigs. Can. J. Anim. Sci. 84:792 (Abstr.). 